house with boat, dredges, and other collecting gear will be added. The whole will be so arranged that additional accommodation may be added when found desirable.

We need not point out the importance of the station proposed to be erected in Sydney. It is expected that most of those who will make use of the station will come from England, and therefore it will be only fair that English biologists should help our Sydney friends to complete the $300 l$. required for the station. There is some fear that they may not be able to raise the whole sum in the colony, and we would therefore strongly urge upon those of our readers interested in the enterprise to lend a helping hand. Dr. J. C. Cox, Hunter Street, Sydney, acts as treasurer, and $\mathrm{Mr}$. George Leslie, assistant to Sir Wyville Thomson, University, Edinburgh, has been asked to become treasurer for any subscriptions that may be raised at home.

Baron Maclay, we may state, is at present engaged in an excursion in Polynesia, and will return to Sydney about the end of the present year.

\section{THE RESIGNATION OF DR. ANDREWS}

$\mathrm{WE}$ learn with great regret that Dr. Andrews has resigned the post he has so long held as vicepresident of Queen's College, Belfast, and Professor of Chemistry. Dr. Andrews had been urged by his brother professors to allow himself to be proposed for the first vacancy in the presidency of the College, but his sense of duty urged him to give a peremptory refusal.

With reference to Dr. Andrews's work both as a professor and as a scientific worker, we quote from an excellent article in the Northern Whig of the I8th inst. :- -

"Before the formation of the Queen's University he had been Professor of Chemistry in the medical school of the Belfast Institution, and from this post he was transferred to a similar chair in Queen's College, while at the same time he was appointed its first vice-president. "The importance of this latter office may be gathered from the fact that to a joint board, consisting of the presidents and vice-presidents of Belfast, Cork, and Galway, was remitted the arduous task of framing statutes and ordinances for the internal management of the colleges, and on this board there was certainly no stronger man than Dr. Andrews. The Queen's Colleges were launched upon the country as a great educational experiment. Founded upon the principle of united secular and separate religious instruction, they had to contend all through their career against opposition of the bitterest and most unscrupulous character. The men, therefore, who actually worked the vessel through its early dangers have deserved well of their country in no small degree, and in the front rank of these stands Dr. Andrews. And not merely was he a practical worker in the cause of united education; he has besides given to the world some of the most effective expositions of its principles. His address on the subject, delivered in 1867 to the Social Science Congress in Belfast, is one of the classics of the question, and it is not too much to say that its influence was powerfully felt in moulding opinion in England in preparation for the Liberal educational policy of 1870 . Nor was he a less well-recognised authority in regard to the general question of university education. His little work entitled 'Studium Generale,' elicited, if we mistake not, by the supplemental charter proposals, contains a most fresh and vigorous enunciation of the most enlightened views upon higher education. As a teacher of science, Dr. Andrews has been most successful. His mastery of the subject found expression in exposition of the clearest and most lucid character, while his faculty of popular experimenting was of the most delicately accurate and attractive character. $\mathrm{He}$ had a peculiar power of gathering about him the élite of the best men of the year; wherever there was a man endowed with somewhat of the true scientific spirit, he was sure to gravitate towards the laboratory; and it is an interesting fact that the great majority of Dr. Andrews's most trusted laboratory students have turned out successful men in after life.

"But, however eminent have been Dr. Andrews's services in the directions already alluded to, it is as an original scientific investigator that he has gained his principal title to an immortal place in the annals of fame. Dr. Andrews belongs to the first rank of that remarkable body of professed chemists whose researches have been more of a physical than of a chemical nature. The names of Faraday, Graham, and Regnault, at once suggest themselves in this connection; and we are quite justified in saying that in insight, accuracy, and originality, as well as in the intrinsic value of their results, Dr. Andrews's investigations will bear comparison with the very best work of these great men. We cannot here attempt to give more than a very brief notice of the results of some of the more important of Dr. Andrews's papers. The complete list will be found in that invaluable work "The Royal Society Catalogue of Scientific Papers," to which all men of science are under the deepest obligations. The most important of his earlier investigations is a brilliant series of determinations of the heat of combination of different classes of substances. Considering the difficulties of this inquiry, as shown by the preposterous results which have sometimes been given even by able experimenters, the simplicity of Dr. Andrews's methods and the recognised accuracy of his results form a striking tribute to his care and skill. The results are not only of high theoretical value as regards the constitution of matter, but also of great importance for practical determinations of the electromotive force of various voltaic combinations. Next we have his grand researches on ozone, a remarkable body first distinctly recognised by Schönbein, whose nature was long a puzzle to chemists. It was reserved for Dr. Andrews to show (I) that ozone, from whatever source derived, is one and the same body; (2) that it is an allotropic form of oxygen. Before he cleared up these points it was generally supposed by chemists that there were different kinds of ozone, and that one of them, prepared by electrolysis, was a teroxide of hydrogen. In a second research Dr. Andrews traced the volumetric changes which occur in the formation of ozone from pure oxygen by the electric discharge-where it has been long known under the name of "the smell of lightning'-and gave a number of similar and very remarkable volumetric changes observed in other gases, simple as well as compound, produced under the same experimental conditions. He showed that the chemical activity of chlorine could be greatly increased, just as that of oxogen was, by electric discharges. This question has again only very recently been reopened by a Continental chemist, who maintains that chlorine is not an element, but a compound body. The most recent of Dr. Andrews's grand contributions to science is his classical research into the 'Continuity of the Liquid and Gaseous States of Matter.' By means of a very simple but exquisite apparatus (prepared for him under his own directions by our very skilful townsman, Mr. Cumine), be showed that it was possible to convert a gas such as carbonic acid into a liquid, or the liquid into the gas, without any discontinuity whatever. In fact, a spectator may watch the body throughout the process, assure himself that it is gas at starting, and that it is liquid at last, and yet not be able to state when the change took place. From the scientific point of view, this phenomenon is best described by the use of Dr. Andrews's discovery of the 'critical point,' as it is called. For every gas or vapour there is a special temperature called its critical point, which is such that only when the temperature of the gas or vapour is under that point can it exist in presence of the liquid; so that the portion liquefied can be distinguished from the 
rest. By these experiments Dr. Andrews cleared up the whole question of the liquefaction of gases by the separate or combined actions of cold and pressure. It is not too much to say that all the essential particulars as to apparatus and mode of working, by which two years ago the liquefaction of oxygen, and even of hydrogen, was effected simultaneously in France and in Switzerland, are to be found in Dr. Andrews's papers. It is to be regretted that the state of his health did not enable him to reap for himself (as he unquestionably would have done) this striking result of his beautiful investigations. But, after all, he has the credit of Adams or Leverrier, he pointed out how and where, with certainty, to find the hitherto unknown; and his glory is none the less that a Challis and a Galle, better provided with the requisite instrumental means, actually obtained the result. The mere fact of the liquefaction of oxygen, or the solidification of hydrogen, though very important in itself, is only one legitimate and inevitable consequence of Dr. Andrews's previous results ; but it is vastly more easy of apprehension by the general public. But in the eye of science the demonstration that it is possible for matter to be made to pass by continuous stages from the gaseous to the liquid conditions forms one of the very greatest discoveries of even the nineteen th century.

"Such is the man whom, for the last half-century, we have had unostentatiously dwelling among us, prosecuting the labours that are only possible to the most exalted intellects of our race. Now that he goes into comparative retirement, there will be surely some means adopted of recognising in a permanent form connected with the college what it owes to him and to his great reputation."

\section{GEOGRAPHICAL NOTES}

$W_{E}$ learn from Oran that the French officers of the Staff in Algeria perceived for the first time on September 9 the electric light from the Spanish station of Tetica, at a distance of 272 kilometres. Commandant Perrier, director of the Algerian Survey, was enabled to measure one angle of the triangle, and the other having been measured from the Agerian station on the mountains, the operation may be considered as having been quite completed, and the junction of the Algerian network with the European triangulation an accomplished fact.

AT the meeting of the International Geodetical Association at Geneva no delegates are reported as having been sent from Sweden, Norway, Denmark, Netherlands, England, or Turkey. France, who resisted during the lifetime of Leverrier, sent MM. Charles Sainte ClaireDeville, Faye, and Yvon Villarceau. Not only was Germany represented by Professors Peters and Rhumkers, but Saxony by M. Bruhns, and Bavaria by M. Baurnfeind. Spain sent General Ibanez, Belgium Col. Adams, Russia General Forsch, Austria Prof. Oppolzer, Italy General Mayo, Prof. Respighi, Col. Ferrera, and Major Maggia; Switzerland had two representatives, Professors Hirsch and Plantamour, the head of the Geneva Observatory. The session was inaugurated by reading the report by $M$. Deville on experiments made by himself and M. Mascart, the director of the Central Bureau of French Meteorology, for the construction of the irido-platinum international metre.

M. Tyaghin, an officer of the Russian Navy, who went in July of last year to Novaya Zemlya with his wife, a child, and three servants to winter at the life-station organised on the island, has just returned to Archangelse. All are well, and the little family has been increased by a new-born child. The winter was not severe, the greatest cold having been only $-29^{\circ}$ I Celsius; and on August I, when M. Tyaghin left Novaya Zemlya, the thermometer rose as high as $16^{\circ}$. The five Samoyede families who were sent to the same station are well, but one old man of more than sixty years and two others died from scurvy, and $M$. Tyaghin explains their death by the circumstance that they never went out of their dwelling and did not follow his recommendations. The bunting was good throughout the winter.

THE Russian Ministries of War and of Public Communications had resolved to send this year no less than three expeditions for the exploration of the old bed of the Amu-darya, and for researches as to the possibility of a water-communication between this river and the Caspian. The troubles in the Turcoman steppes hindered the starting of two of the expeditions which were to explore the steppes between Khiva and Krasnovodsk, and their departure has been postponed until January next. The third expedition has already started, and it is now engaged in the exploration of the Amu Darya River, and of its delta.

M. Sibiryakoff publishes in Russian papers a telegram which he has received from Capt. Glasö, who tried this summer to enter the Kara Sea, and sail to the mouth of the Yenisei, on board the steamer Samuel Owen. All three fassages, the Matochkin, the Kara, and the Yugor Straits, were encumbered with ice, and Capt. Glasö returned on August 26 without attempting the passage around the northern extremity of Novaya Zemlya.

ON July 28 last Dr. Gerhard Rohlfs' expedition left the Casis of Batifal, situated at some twenty-eight kilometres distance from Djalo, in order to reach the northernmost Oasis of Siren in seven days, and Istat, the principal place in the southern Oasis of Kebalo, in the Kafra Group in twelve days. Dr. Rohlfs expected to arrive at Wadai in the middle of October. This results from a letter written by his companion, Dr. Stecker, to Prof. von Hochstetter, of Vienna. Another letter, written to a friend at Prague, states that Dr. Rohlfs will leave the expedition either at Wadai or even at Kafra, and return to Europe. Dr. Stecker will then continue the journey alone. It will be remembered that Dr. Rohlfs had already resolved to resign the leadership, but on second thoughts decided to remain. His final resignation is much to be regretted.

THE Imperial Geographical Society of St. Petersburg intends to form a connection with other institutions of the Russian Empire with a view of editing, in conjunction with them, a general description of Siberia with maps and plans, upon the occasion of the approaching tercentenary of the occupation of Siberia by the Russians. The Society will undertake the purely geographical part: of the work and will also publish a bibliographical review of all other works on Siberia hitherto published.

THE International Society for the exploration of Equatorial Africa is very busy opening commercial relations between the settlements at the mouth of the Congo River and the interior. A few weeks ago the steamer Barga left Antwerp with European merchandise for this purpose. The steamer also takes out three small steam launches, a small steamer which will hold about thirty passengers, and three large goods-barges. By means of these the lower cataracts and rapids of the Congo will doubtless soon be reached. It is intended to establish stores at that point on both banks of the river. The question then will be to make a road along the river up to that point, where it again becomes navigable.

THE Imperial "Leopoldinisch-Carolinische" German Academy of Naturalists at Halle, which possesses the right of conferring doctor-diplomas, has lately bestowed this honourable distinction upon the three eminent travellers, Julius Payer, Karl Weyprecht, and Henry M. Stanley.

THE Berlin Geographical Society will celebrate the centenary of the birth of Karl Ritter, which happened on August 7, 1779, after the vacation, i.e. in Cctober next. 